This is the post-peer review final draft of a paper published in Water Research. The final

publication is available at IWA Publishing http://www.iwaponline.com

(DOI:10.1016/j.watres.2017.02.056)

\title{
Urban rainwater harvesting systems: research, implementation and future perspectives
}

Alberto Campisano a*, David Butler b, Sarah Ward b, Matthew J. Burns c, Eran Friedler d, Kathy DeBusk e, Lloyd N. Fisher-Jeffes f, Enedir Ghisi g, Ataur Rahman h, Hiroaki Furumai i, Mooyoung Han ${ }^{\mathrm{j}}$

$a^{*}$ Department of Civil Engineering and Architecture, University of Catania, Viale A. Doria, 6, 95125, Catania, Italy, corresponding author, email: acampisa@dica.unict.it

b Centre for Water Systems, College of Engineering, Mathematics and Physical Sciences, University of Exeter, Exeter, EX4 4QF, UK

c Waterway Ecosystem Research Group, School of Ecosystem and Forest Sciences, University of Melbourne, Burnley, Australia

d Department of Environmental, Water \& Agricultural Engineering, Faculty of Civil and Environmental Engineering, Technion-Israel Institute of Technology, Haifa 32000, Israel

e Biological and Agricultural Engineering, North Carolina State University, Campus Box 7625, Raleigh, NC 27695, USA

f Department of Civil Engineering, University of Cape Town, Private Bag X3, Rondebosch, South Africa

g Federal University of Santa Catarina, Department of Civil Engineering, Laboratory of Energy Efficiency in Buildings, Florianópoli, SC, Brazil

h School of Computing, Engineering and Mathematics, University of Western Sydney, Sydney, Australia

i Research Center for Water Environment Technology, The University of Tokyo, 7-3-1 Hongo, Bunkyo-ku, Tokyo 113-8656, Japan

j Department of Civil and Environmental Engineering, Seoul National University, 1 Gwanak-ro, Gwanak-gu, Seoul, South Korea

ABSTRACT

While the practice of rainwater harvesting (RWH) can be traced back millennia, the degree of its modern implementation varies greatly across the world, often with systems that do not maximize potential benefits. With a global focus, the pertinent practical, theoretical and social aspects of RWH are reviewed in order to ascertain the state of the art. Avenues for future research are also identified. A major finding is that the degree of RWH systems implementation and the technology selection are strongly influenced by economic constraints and local regulations. Moreover, despite design protocols having been set up in many countries, recommendations are still often organized only with the objective of conserving water without considering other potential benefits associated with the multiple-purpose nature of RWH. It is suggested that future work on RWH addresses three priority challenges. Firstly, more empirical data on system operation is needed to allow improved modelling by taking into account multiple objectives of RWH systems. Secondly, maintenance aspects and how they may impact the quality of collected rainwater should be explored in the future as a way to increase confidence on rainwater use. Finally, research should be devoted to the understanding of how institutional and socio-political support can be best targeted to improve system efficacy and community acceptance.

Keywords: Rainwater harvesting, stormwater management, sustainable urban water systems, water 
conservation, water efficiency.

\section{Introduction}

Rainwater Harvesting (RWH) is probably the most ancient practice in use in the world to cope with water supply needs. In recent decades, as a result of new technological possibilities, many countries are supporting updated implementation of such practice to address the increase in water demand pressures associated with climatic, environmental and societal changes (Amos et al., 2016). In urban areas, RWH consists of the concentration, collection, storage and treatment of rainwater from rooftops, terraces, courtyards, and other impervious building surfaces for on-site use. Civil uses of collected rainwater are disparate (e.g. toilet flushing, laundry, garden irrigation, terrace cleaning, and other sporadic out-door uses such as car washing), but all aim to reduce consumption of drinking water from centrally supplied sources. GhaffarianHoseini et al. (2016) suggest these uses can globally account for $80-90 \%$ of overall household water consumption, and highlight the significant water conservation benefits associated with RWH implementation. Consequently, installation of RWH systems increases water self-sufficiency of cities and can help delay the need to construct new centralized water infrastructures (Steffen et al., 2012).

Water scarcity and need for water supply augmentation are not the only reasons that have motivated municipalities to boost RWH system installation. In fact, consolidated scientific and grey literature of the last twenty years shows that RWH belongs to the large family of detention-based Low Impact Development (LID) or Sustainable Drainage System (SuDS) approaches and can be adopted as a complementary measure to reduce frequency, peaks and volumes of urban runoff if systems are appropriately designed. The increase of urban-catchment distributed detention by tank-based RWH systems (and other at-source technologies) may reduce the impacts of urbanization growth on the stormwater drainage system (Brodie, 2008; Burns et al., 2015) and possibly contribute to the mitigation of environmental impacts on receiving water bodies (e.g. Hamel and Fletcher, 2014). For example, studies from Australia show that the installation of rainwater tanks at the allotment scale could return the rainfall-runoff response of the impervious roof close to pre-development levels 73 (Burns et al., 2012a) and reduce disturbance of the catchment water quality regimes (Burns et al., 
2012b). Multiple-usage demands ensure a relatively continuous use of the water, thereby maximizing rainfall capture by creating room in the storage tank for upcoming rain events (Domènech and Saurí, 2011; Gardner and Vieritz, 2010). Incorporating demands that align with local rainfall patterns can substantially increase the efficiency of the system in terms of both water conservation and stormwater mitigation (Zhang et al., 2009).

When used in conjunction with infiltration-based solutions, excess overflow water from RWH systems (that would otherwise generate street runoff or enter the storm sewer network) can be infiltrated (often after preliminary treatment, as determined by national regulations) for groundwater recharge (Dillon, 2005). Recent studies have shown that infiltration techniques coupled with RWH can also help in modifying the urban microclimate by increasing moisture content and evapotranspiration (e.g. Hamel et al., 2012), so mitigating the heat island phenomenon (Furumai, 2008; Coutts et al., 2012). Environmental benefits concerning the reduction of emissions and the decreasing of consumed resources with RWH system implementation have been explored in recent years (e.g. Angrill et al., 2012). In this regard, the scientific literature shows that the selected use of rainwater in the building and the type of implementation project (renovation or new construction) significantlyaffect the economic viability of the system (Devkota et al., 2015; Morales-Pinzón et al., 2015).

The implications of RWH for energy consumption are currently contested. Parkes et al. (2010) suggest that the water supplied by RWH systems typically requires greater operational energy to deliver than dependent and in fact technological innovation in pump design and in low- or no-energy RWH systems makes this less of an issue going forward. Jiang et al. (2013), for example, found that RWH systems may lead to a decrease of energy usage. Other projects are using harvested rainwater within houses for thermal energy recovery and building cooling (An et al., 2015; Kollo and Laanearu, 2016). The literature clearly shows that the range of applications of RWH systems in urbanized areas is very large. However, the results and the perception of the extent of potential benefits are varied and 
competing) RWH systems are still at an embryonic stage. In this light, a critical review of the state of

102 the art of application of RWH systems is carried out in this paper to clarify some key aspects that may 103 determine their successful implementation. The context addressed is that of systems in urban areas 104 already serviced by centralized water infrastructure. The paper is organized as follows. A focus on types and complexities of implemented systems according to the different potential objectives of RWH is firstly presented in section 2 . Section 3 briefly explores the degree of application of RWH in the world's continents highlighting experienced benefits and drawbacks. A review of results concerning water quality aspects as well as treatment requirements of urban RWH is reported in section 4 . Advantages and limitations of approaches to model the RWH system behaviour and performance are examined in section 5. Section 6 critically discusses financial feasibility of RWH installations while section 7 explores social aspects as well as other non-technical issues associated with governmental policies. Finally, section 8 explores research needs and future perspectives for the development of RWH systems in urban environments.

\section{Characteristics of rainwater harvesting systems}

\subsection{Conventional systems}

Fig. 1 shows the configuration of a typical system for on-site RWH and the interaction of its main components. Design configurations and installation protocols for RWH systems have been defined in design guidance and implementation manuals across the globe (e.g. Deutsches Institut für Normung, 1989, Texas Water Development Board, 2005, Master Plumbers and Mechanical Services Association of Australia, 2008; British Standards Institute, 2013). The core component of each RWH system is the rainwater tank that allows implementation of the basic functions of storage and treatment of the collected rainwater. Typically, the collection surface is the building rooftop, but other impervious catchment surfaces (normally those closely associated with the building) can be connected to the tank. During rain events, generated runoff is delivered to the tank via the collection system (usually a system of gutters and downspouts) and temporarily stored in order to match demand for rainwater 
128 the rainwater tank to appliances and/or taps for rainwater use. One or more pumps are commonly 129 (but not exclusively) adopted to assure appropriate pressure head for the various uses. 130 Complementary devices for quality control are first flush diverters, debris screens, and filters. 131 Diverters separate and convey the more polluted part of the runoff volume to the sewer system, while 132 screens and filters are used to intercept solids (sediment, debris, leaves, etc.) and particulate matter to 133 prevent them from entering the tank (Abbasi and Abbasi, 2011).

134 A critical point of the design of domestic RWH systems is the type of tank to use for rainwater storage. 135 Although non-potable use is expected in the large majority of cases, the demand type plays an 136 important role in tank selection. The technology offers a range of tanks from above-ground "rain 137 barrels" (normally plastic or metal containers of a few cubic meters capacity) typically used for 138 irrigation purposes and runoff control in single-household residential buildings, to above- or below139 ground concrete cisterns (of larger size) oriented to multi-storey buildings and multi-purpose RWH 140 including large demanding in-door and out-door uses. Field experience has shown that, although high 141 capacity storage tanks may increase the benefits of RWH systems, limited space can often prevent 142 their installation (GhaffarianHoseini et al., 2016).

\subsection{New systems}

145 Innovation in system configuration is ongoing globally with systems ranging from fractioning of 146 storage by use of interrelated modular systems and collapsible tanks (Dao et al., 2009) to gutter-based 147 collection and storage (Hardie, 2010) or other high-level, low-energy systems (Melville-Shreeve et al., 148 2016), each aiming to fit with the pressures of different contexts.

Recent projects have considered the incorporation of dual storage facilities into RWH system 151 installations (Brodie, 2008) with separate tank units designated for both stormwater detention and 152 retention storage objectives. The retention storage volume is designed to meet user demands and the 153 detention storage volume (normally comprising the top portion of the storage tank) serves as a 154 temporary holding space for runoff control. The two storage volumes may be connected by a small 
orifice that allows the water in the detention portion to slowly drain out and leave space in the tank prior to the next rain event (Gee and Hunt, 2016).

The need to address objectives that often mutually conflict (i.e. maximizing water saving, maximizing empty tank volume for runoff control, minimizing costs, etc.) requires customizing RWH systems in order to maximize their return on investment. More complex systems than illustrated in Fig. 1 can incorporate the combined use of the RWH module with other system facilities (i.e. infiltration systems, rain gardens, bio-retention cells, etc.). Such facilities can allow management of tank overflows, first flush diversion or dual storage release (Herrmann and Schmida, 2000; Kim and Yoo, 2009).

Fig. 1. here

More advanced technological options and ICT can also be implemented by adding sensors to the tank system equipment. Though increasing system complexity, such Supervisory Control And Data Acquisition system (SCADA)-based devices can improve the automation and control of RWH systems for optimal management of stored rainwater resources (Han and Mun, 2011; Gee and Hunt, 2016).

\section{Degree of application in various countries}

\subsection{Africa}

In addition to the use of harvested rainwater by communities/individuals in large cities, RWH in Africa includes experience gained in small urban settlements where communal RWH systems have been developed in areas which ordinarily would be considered rural.

Gould (1993) provides a comprehensive overview of RWH in Africa and the state of the art up until 1994. Whilst little has changed in the last 20 years, there is evidence of the continued and increasing role of Non-Governmental Organisations (e.g. UNESCO, SIDA, UNEP), and research organisations in promoting and supporting the use of RWH through a range of activities - typically focused, 
understandably, on the poor. A number of studies (e.g. Handia et al., 2003; Fisher-Jeffes, 2015) have shown that RWH could provide a substantial water source across the continent. Large survey projects making use of GIS tools have shown opportunities for RWH in selected countries of Africa such as Botswana, Ethiopia, Kenya, Malawi, Mozambique, Rwanda, Tanzania, Uganda, Zambia, and Zimbabwe (Mati et al., 2006).

This has led to the spread of RWH across Africa, and the formation of Rainwater Harvesting Associations in a number of countries. In many parts of the continent RWH is practised as a result of economic rather than physical water scarcity - meaning there is adequate water available for use, but a lack of infrastructure to store, treat and transport it to where it is needed. Furthermore, while governments are generally supportive of RWH, it is evident that this support (from all sectors) is overwhelmingly for rural and poor communities.

Small-scale communal RWH (i.e. where a pond/storage tank is used to collect runoff and provide water for a number of households, or for a large public building) is probably the most diffused level of application of RWH in Africa (e.g. Dobrowksy et al., 2014). Recently, commercial/industrial companies have taken an interest in alternative water resources, including $\mathrm{RWH}$, at industrial site scale for a variety of end-uses including irrigation and cooling. Conversely, research has indicated that domestic RWH is only economically viable for a minority in urban areas - with large roofs and high demand or for isolated households without other water sources (Fisher-Jeffes, 2015).

\subsection{Asia}

RWH plays an important role in many Asian countries. For example, much work has been done in Japan where, from the early 1980s, local governments started promoting the introduction of water recycling systems as an effective mitigation countermeasure for large cities facing both water scarcity 
and urban flood problems. Since then, RWH has been actively introduced in large public and private

210 buildings also thanks to the support by local municipalities promoting special finance programmes.

212 Fig. 2 shows the results of a survey providing the number of public facilities and office buildings using 213 RWH systems in Japan over the last four decades (MLIT, 2014); it indicates the number of RWH 214 systems increases significantly after the introduction of the governmental financial support, with 10 215 times more installations recorded at the end of 2012 as compared with 1990. However, significant 216 improvements are expected, given that rainwater usage $\left(7,8 \mathrm{Mm}^{3} /\right.$ year $)$ was estimated to about $0.01 \%$ 217 of the water usage throughout the country.

Fig. 2. here

The detailed analysis of a sample of over 250 different RWH facilities at national level revealed a large variety of installed tank systems. Almost 30\% of the systems are installed in schools and university buildings with tank sizes ranging between $8-1000 \mathrm{~m}^{3}$. Another $15 \%$ is installed in public offices with maximum tank storage capacity of the tank of $1500 \mathrm{~m}^{3}$. Small-size RWH facilities placed in individual houses (storage capacity less than $1 \mathrm{~m}^{3}$ ) are wide-spread in Japan. Although statistical data on the use of small tanks is not available nationwide, the Great East Japan Earthquake in March 2011 caused a sudden rise in the number of households that installed tanks to store rainwater for emergency.

In recent decades, RWH is being revisited also in South Korea as an adaptation strategy for coping with climate extremes, especially in highly developed urban areas. Emphasis is being given to large-scale RWH projects (Han and Mun, 2011). Ongoing discussion in South Korea to support RWH concerns the development of incentive tools/schemes to reimburse the energy saved from using rainwater in private houses. 
The low-cost implementation of RWH systems has also been supported in Thailand. The Thai government embarked on an extensive national program for $\mathrm{RWH}$, using jar tank systems of various capacities (from 0.1 to $3 \mathrm{~m}^{3}$ ). These have been installed in many villages for drinking water purposes and have been shown to provide sufficient harvested rainwater for household use during the dry season, lasting up to six months (Wirojanagud and Vanvarothorn, 1990).

In the Gansu province, China, a demonstration project on RWH has been carried out with very positive results in the recent decades (Gould et al., 2014). Up to the year 2000, the project has led to building more than 2 million rainwater tanks with a total capacity of more than 73 million $\mathrm{m}^{3}$ supplying drinking water for almost 2 million people and supplementary irrigation for more than 230,000 ha of land. Based on these results, seventeen provinces have adopted RWH systems starting from the year 2001 and built more than 5.5 million tanks for drinking water and supplemental irrigation throughout 249 China.

In 2009, the Taiwan Water Resources Agency included RWH in the Taiwanese Water Law as alternative source for domestic water supply. The new policy (MI, 2013) requires, for example, that all new buildings with a total floor area larger than $10,000 \mathrm{~m}^{2}$ must install domestic RWH equipment to supply at least $5 \%$ of the total water required by the building.

\subsection{Australia}

Australia has one of the highest degrees of the implementation of RWH systems. According to the results of a survey by the Australian Bureau of Statistics (ABS, 2015), about 1.7 million households had fitted rainwater tanks to their households. These tanks provided approximately 156 GL of water approximately 8\% of household water use - during 1 July 2013 to 30 June 2014 (one year period), 260 which is equivalent to AU\$507 million. As of March 2013, approximately 34\% of Australian 261 households that could fit a rainwater tank had a tank as compared to $32 \%$ in 2010 and $24 \%$ in 2007. 262 The increase is attributed to water restrictions imposed by water authorities, rebates provided by government authorities, favourable water regulations and water pricing factors (ABS, 2015). 
Interestingly, out of all the households fitted with a rainwater tank, households outside of the state capitals had the highest rate (44\%) of implementing RWH compared to households in the state capitals (only 28\%). Across both rural and urban areas, around half of the RWH systems were connected to indoor end-uses. Finally, the survey found that the biggest motivator to install a RWH system was to save potable water ( $49 \%$ of the people fall in this category).

RWH seems to have been successfully implemented across Australia. For example, $77 \%$ of the households did not have any problem with their RWH system in the 12 month period reported on in the survey; though in general, pump malfunctioning was reported to be the most common problem (41\% of reported problems). The maintenance of RWH systems was undertaken by $58 \%$ of all the tank owners, which typically included cleaning of roof gutters.

Field performance of RWH systems in reducing potable water demand in Australia was quantified in a study by Burns et al. (2015). The study reports observed potable water reductions in the range of 10 $100 \%$ from continuous monitoring of twelve household-scale RHW installations. Not surprisingly, the largest such reductions were associated with households featuring tanks connected to multiple indoor demands (toilet flushing, cloth-washing, and hot water usage). Similar field experiments by Umapathi et al. (2012) revealed potable water savings of 1-67\% (mean equal to 31\%) for 20 allotments in Queensland and multiple in-door demands and external demand for garden watering.

Beyond the household scale, there is limited data on RWH system use in Australia. Experience shows that RWH systems are also used in public areas for the irrigation of gardens and sporting ovals. Such systems tend to be installed, operated and maintained by local government. The prevalence of these more large-scale systems increased markedly in the 2000s because of severe water restrictions as a consequence of extreme drought conditions that persisted in south-eastern Australia for around 10 years. 
The status of implementation of RWH systems in European countries is varied. Several countries in 293 Western Europe use RWH systems to conserve municipal water supplies. In the UK, traditionally 294 people have collected and stored rainwater for household use (laundry, washing up and other cleaning operations). However, modern RWH systems have only been introduced relatively recently. One of the reasons is that suitable codes and standards for RWH (including BS 8515:2013 and BS 8595:2013) have only relatively recently become available and anticipated incentives and adaption mechanisms for charging for harvested rainwater have not been forthcoming from governing, regulatory or water management organisations in the UK (Ward et al., 2014). Commercial-scale systems, such as those installed in supermarkets, schools and office buildings, are currently more widespread due to their greater financial viability than household-scales systems, though innovation in smaller systems may see the latter increase in the future (Melville-Shreeve et al., 2016). The UK community for sustainable drainage, 'Susdrain', has compiled an inventory of case studies (http://www.susdrain.org/casestudies/).

Currently, Germany is a leader in promoting the widespread use of this technology for domestic use. As a consequence of the promotion (by grants and subsidies) of household RWH at the local government level (Schuetze, 2013), today almost one third of new buildings built in Germany are equipped with a rainwater collection system. Due to serious industrial air pollution and strict regulations regarding drinking water standards, household rainwater supplies are fundamentally

311 limited to non-potable uses focusing mainly on irrigation, toilet flushing, and laundry use. Spain has undertaken a programme of incentives and subsidies for new buildings (Domènech and Saurí, 2011).

313 While, in the year 2008, France enacted a regulatory framework (De Gouvello et al., 2014) to 314 encourage the use of rainwater through tax credit (although this is now abolished). Technical 315 guidelines for RWH have also been issued in Italy (UNI, 2012). Since then, several communities 316 promote RWH as complementary technology to improve urban runoff control and irrigation of public 317 and private green spaces. The popularity of installing RWH systems is also increasing in other 
countries such as Austria, Switzerland, Belgium and Denmark, with the potable water price being the main driver (Godskesen et al., 2013; Ringelstein, 2015). A good example of RWH practices within water sensitive and sustainable urban development is Hammarby Sjöstad in Stockholm, Sweden, which incorporates RWH as well as street runoff collection (Iveroth et al., 2013).

\subsection{Americas}

The level of application of RWH in the Americas varies depending on the country, even state, considered.More than 100,000 residential RWH systems are in use in the USA (Lye, 2002) in the form of simple rain barrels for garden irrigation at the end of roof downspouts, or of complex large-scale multiple end-use systems including potable use. Texas is probably the state with the highest level of implementation. Harvested rainwater in Texas helps a number of water-scarce communities to reduce the gap between supply and demand (Texas Water Development Board, 2005). The State of Texas offers financial incentives for RWH systems exempting RWH equipment from sales tax. Cities of Austin and San Antonio use local subsidy-based tools to encourage construction of RWH systems as a measure to conserve water. Rainwater harvesting from roof surfaces is allowed also in other states (e.g. Oregon, New Mexico) with strict requirements needed for the uses of rainwater. Thousands of systems have been installed in these areas going from "do-it-yourself" rain cistern for watering food gardens to tanks for fire suppression at the scale of community.

\section{Research results from the field (Debusk et al., 2013) have been based on monitoring different RWH} systems in south-eastern U.S.A. Two of the systems monitored - which supplied water for flushing animal kennels and the irrigation of greenhouses - reduced potable water demand by 100 and $61 \%$ respectively. Conversely, Jones and Hunt (2010) showed minimal potable water reductions obtained from three different RWH systems supplying rainwater for toilet flushing, irrigation and car washing.

The potential benefits of RWH in South America have been assessed, and pilots implemented, in a number of places. For example, in 2001, the "One Million Cistern" RWH programme was launched in 
344 Brazil. It aimed to benefit about two million people (more than 350,000 cisterns constructed) living in 345 semi-arid rural settlements with no source of potable water nearby (De Moraes and Rocha, 2013). 346 Gomes et al. (2012) assessed such a programme by surveying 623 beneficiaries. The survey 347 highlighted the main problems that prevented adequate functioning of the RWH units (e.g. the poor 348 quality of the roof, the small storage capacity of cisterns, and the absence of automatic devices for the 349 first flush diversion). In Brazil, Marcynuk et al. (2013) highlight that households with access to 350 rainwater from cisterns were associated with a minor risk of infections compared to households 351 supplied by other water sources - typically sources with no sanitary protection, including rivers, 352 springs and dams. However, there is still debate over the ways to incentivise and charge for the use of 353 RWH in Brazil (Ward et al., 2014).

In Central America, the Isla Urbana initiative in Mexico City has enabled the harvesting of $170 \mathrm{ML}$ of roof runoff to alleviate water scarcity and local flood problems (Isla Urbana, 2016).The initiative allowed displacement of "pipas" (water trucks widely used to supply water to households) and is now expected to be a boost for future development of specific regulations regarding RWH across Mexico. Further, in the Bahamas, Bermuda, and other Caribbean islands, rainwater cisterns must be included in all new constructions under governmental economical support. For instance, rebates of $\$ 0.50$ per gallon of installed tank capacity are offered as an incentive by the Barbados Water Authority. In other areas of South and Central America, RWH implementation is mainly at the stage of research/planning evaluation (Waller et al., 2001; Lizárraga-Mendiola et al., 2015).

\section{Quality assessment of harvested rainwater}

\subsection{Metals and nutrients}

The quality of harvested rainwater depends largely upon the materials used to construct the RWH system and the environment in which it is located (Lee et al., 2010). Despite rooftop surfaces being comparatively cleaner than parking lots, sidewalks and other impervious surfaces, rooftop runoff can 
371 Sources of pollutants in rooftop runoff include precipitation (i.e. wet deposition), atmospheric 372 deposition (i.e. dry deposition) and materials used in the construction of the roof (Abbasi and Abbasi, 373 2011)

374 One of the most prominent issues with the quality of the collected rainwater is the phenomenon of 375 acid rain, which can result in low pH levels in areas characterized by high vehicle traffic volumes, high376 density residential development and industry (Olem and Berthouex, 1989; Melidis et al., 2007). In 377 addition, numerous other pollutants have been measured in rainwater due to their presence in the 378 atmosphere. In East Texas, U.S.A., rainwater concentrations of copper $(\mathrm{Cu})$ and zinc $(\mathrm{Zn})$ exceeded 379 U.S.A. Environmental Protection Agency (USEPA) freshwater quality standards of 0.013mg/l and $380 \quad 0.12 \mathrm{mg} / \mathrm{l}$, respectively, due to industrial emissions from petroleum refining, petrochemical production 381 and forest products production (Chang et al., 2004). Elevated total suspended sediment (TSS) concentrations in rainwater sampled by Adeniyi and Olabanji (2005) in Nigeria were most likely 383 caused by agricultural bush burning and dust mobilized by vehicle traffic. Constituents in collected 384 rainwater that have been linked to dry deposition include TSS, $\mathrm{Pb}$ (due industrial emissions), chloride 385 (Cl) (due to application of de-icing salts in the winter), $\mathrm{Cu}$, nitrates (due to agricultural fertilizer 386 applications), nitrites, Zn, Al, Fe and Ca (Morrow et al., 2010; Mendez et al., 2011).

387 Wash off of the particulates that have accumulated on the roof surfaces since the prior precipitation 388 event is another important sources of constituents. The antecedent dry period plays a role in the 389 accumulated deposition and, thus, in the concentration of pollutants in runoff (Quek and Förster, 390 1993; Thomas and Greene, 1993; Förster, 1999). Yufen et al. (2008) reported an increase in total 391 nitrogen (TN) and total phosphorus (TP) concentrations as the number of preceding dry days without 392 precipitation increased. Numerous studies have also confirmed that roof runoff exhibits a first flush 393 effect in which the majority of the matter collected on a roof surface is washed off during the 394 beginning (1-2 mm of runoff) of a precipitation event (Quek and Förster, 1993; Yufen et al., 2008; Kus 395 et al., 2010a). Concentrations usually decrease as rainfall continues (e.g. Kus et al., 2010b).

396 In addition to wet and dry deposition, roofing materials can serve as a significant source of 397 contaminants in roof runoff (Melidis et al., 2007; Despins et al., 2009; Clark et al., 2008; Akoto et al., 
2011). Roof materials contribute dissolved and particulate matter to roof runoff due to weathering processes and chemical and physical reactions occurring between the rainwater and the materials

400 (Zobrist et al., 2000). Several studies have shown that rough roofing surfaces, such as asphalt shingles, 401 trap and retain particles and pollutants more so than smooth materials and can have a detrimental effect on harvested water quality (Bradford and Denich, 2007; Despins et al., 2009, Farreny et al., 2011). Thus, materials that contain constituents prone to leaching, such as zinc or copper, should be avoided in case of implementation of a RWH system (Bradford and Denich, 2007).

In addition to the roofing materials, gutters (i.e. drainage system) have been identified as major contributors of heavy metals to roof runoff, especially Zn and Al (Förster, 1999; Lee et al., 2010). Protective coatings are often applied to the outside of metal downspouts to protect the material from corrosion; however, runoff water comes into contact with the unprotected inside. Applying protective coatings to the inside of downspouts may be a way of preventing metal contamination of harvested 410 rainwater from gutters and downspouts (Ward et al., 2010).

411 Several studies have identified distribution piping as another significant contributor of contaminants 412 within RWH systems (Morrow et al., 2010; Martin et al., 2010). Simmons et al. (2001) also observed 413 higher concentrations of $\mathrm{Cu}$ in water that had passed through copper piping. Aging galvanized iron 414 piping could also contribute to elevated Fe concentrations in tap water (Martin et al., 2010). Ward et 415 al. (2010) suggest that the selection of plumbing materials be determined by the hardness of 416 rainwater in the given area to minimize the potential leaching of metals and the consequent 417 deterioration of harvested rainwater.

\subsection{Microbial quality of rainwater}

420 The microbial quality of harvested rainwater is an important factor affecting the possibilities of using 421 the water for both in-door and out-door purposes.

422 The microbial populations in collected and stored rainwater may exhibit substantial variations 423 between different locations (Table 1), depending on climatic conditions (e.g. wind speed and direction, 424 regime of rainfall events), existence of first-flush, and the type of wild life (e.g. birds, cats or foxes) that 
may come in contact with the collection surface. While it is recognised that birds act as a major source of pathogens, other sources include dry deposition (of particles large enough to carry microorganisms) or by wet deposition (during rain events). Another factor that affects the microbial quality of rainwater is the length of antecedent dryness. Most studies report that longer periods of dry-weather are linked to higher microorganism levels due to increased deposited animal faeces on the roof surface (e.g. Yaziz et al., 1989).

Table 1 here

The design of the roof and the rainwater harvesting system, as well as material selection also appear to affect the microbial quality. Literature indicates that inappropriate design and material selection promote contributions from avian sources and inhibit cleaning activities, thus resulting in lower microbial quality of harvested rainwater. The two most detected pathogens, as reported in a review by Fewtrell and Kay (2007a, 2007b), were Salmonella spp. and Campylobacter spp. (Table 1). These authors further report that many of the pathogens isolated from roof-harvested rainwater may not be infective to humans. Albrechtsen (2002) investigated the microbial quality of rainwater collected in seven Danish rainwater harvesting from roofs supplying water for toilet flushing. The study found that the microbial quality of the water was similar to that of tap water used in the cistern, but in $44 \%$ of the samples one or more pathogen specie was observed, meaning that untreated rainwater potentially introduced pathogenic microorganisms into the households which would normally not be found in toilets supplied with water from the distribution system.

\subsection{Rainwater treatment}

The storage tank provides an opportunity for water quality improvement due to increasing $\mathrm{pH}$, sedimentation of particulates and precipitation of heavy metals (Despins et al., 2009; Olem and Berthouex, 1989). 
Sedimentation plays a primary role in the reduction of contaminant loads within the tank, as

454 particulates settle out rather quickly once water enters the storage tank (Sung et al., 2010). In addition

to sedimentation, water quality improvement occurs via sorption and precipitation, especially when $\mathrm{pH}$ is neutral or alkaline (Olem and Berthouex, 1989). These treatment processes are most likely the cause of a generally better quality of stored water compared to roof runoff, and, in many cases, led to compliance with potable water guidelines and standards (Ward et al., 2010; Sazakli et al., 2007).

The potential of water quality contamination throughout RWH systems necessitates the use of different treatment options to produce water of suitable quality for potable and non-potable uses. As discussed in section 2, potential treatment options for RWH systems include both pre-storage (debris screens and filters and first-flush diversion) and post-storage measures (post-storage filtration, clariflocculation and disinfection). The majority of studies on harvested rainwater quality acknowledge that first-flush diversion can significantly improve the quality of collected rainwater and recommend this as a staple in RWH system design (Abdulla and Al-Shareef, 2009; Despins et al., 2009). Diverting the first flush can retard the build-up of particulates and sediments within storage tanks, prevent odour and aesthetic problems (e.g. coloration, visible organic matter) and improve overall water quality (Lee et al., 2010; Abbasi and Abbasi, 2011). It is also highly recommended as a method for decreasing the concentrations of pesticides and other organic compounds that enter the storage 471 tank (Zhu et al., 2004). The diversion volume recommendation varies greatly. Some examples of 472 recommended first flush amounts provide from $40 \mathrm{~L}$ per $80-90 \mathrm{~m}^{2}$ of rooftop (about $0.5 \mathrm{~mm}$ rainfall), to 473 200L per $100 \mathrm{~m}^{2}$ of rooftop (2 mm rainfall) (Abbasi and Abbasi, 2011).

474 Abbasi and Abbasi (2011) recommend the following three characteristics to maximize the 475 effectiveness of debris capture when employed by a RWH system: i) Filters should be easy to clean; ii) 476 Filters should not clog easily and clogging should be easy to detect and rectify; and iii) Filters should not provide an entrance for additional contamination (e.g. corrodible materials, openings large enough to allow animals to access the system. etc.). Recent low-cost technology in this specific field includes new gravity-based self-cleaning filters for installation before the tank storage (Vieira et al., 2013). 
Post-storage treatment can consist of in-line sediment filters on pumps, slow sand filtration, clari481 flocculation and/or disinfection. Particle filtration (sediment filters, sand filtration, other types of 482 filters), have been shown to remove particulates and heavy metals and improving turbidity (Despins et al., 2009). Adding a flocculent such as alum or calcium hydroxide to the storage tank promotes flocculation and settling of suspended fine particulate matter (Abbasi and Abbasi, 2011). Finally, disinfection methods include bleaching powder, potassium permanganate, iodine, heat (boiling water), chlorine, ultraviolet light and ozonation. A recent study from the UK by Ward et al. (2017) investigated the use of a novel treatment train combining filtration, UV and ozonation in a compact point-of-use device. Water quality monitoring across three international field trial locations demonstrated the point-of-use (POU) device could successfully treat harvested rainwater to potable standard. Each of these options has pros and cons to its use; however, disinfection is predominantly used to improve microbiological quality of water. Various low-cost treatment options have also been proposed in water scarce areas of developing countries. For example, treatment of rooftop rainwater by combination of plant coagulant use (Moringa stenopetala seed), sand filter and boiling showed to reduce coliforms 494 and turbidity for potable water supply in Ethiopia (Taffere et al., 2016).

Although first flush diversion and pre-storage filtration can substantially improve the quality of water stored in a rainwater harvesting system, frequent maintenance of these systems is just as important. Numerous studies have found that regular maintenance improves water quality (Magyar et al., 2007; Abdulla and Al-Shareef, 2009). Tasks that should be performed regularly include cleaning the catchment surface, gutters and storage tank, cleaning filters, first flush diverters and debris screens, and inspecting the system for possibly points of entry for mosquitoes and vermin (Kus et al., 2010b).

\section{Current trends in rainwater harvesting systems modelling}

Modelling tools and methodologies have been developed over the last 20 years to facilitate the evaluation (and design) of RWH systems. Key studies have focussed on objectives associated with matching water availability (e.g. rainfall) with water demand (Dixon et al., 1999; DeBusk and Hunt, 2014; Melville-Shreeve et al., 2016). As both rainfall and water demand are temporally variable, RWH 
evaluation models are frequently used as a design tool to calculate the volume of storage required to

508 balance these inflows and outflows, such that the water demand is adequately met for a specific 509 building or location.

511 Tank design approaches include methods based on the use of empirical relationships (Ghisi, 2010; 512 Palla et al., 2011), stochastic analysis (Cowden et al., 2008; Basinger et al., 2010), and continuous mass 513 balance simulation of the tank inflow and outflow (Fewkes and Butler, 2000; Liaw and Tsai, 2004; 514 Campisano and Modica, 2012; Sample and Liu, 2014). Mass balance models combine simplicity of 515 application with appropriate description of rainfall and water demand dynamics at a variety of spatial 516 and temporal scales (Campisano and Modica, 2015; Melville-Shreeve et al., 2016) with the possibility 517 to account also for uncertainty (Mitchell, 2007; Lash et al., 2014). Typically RWH mass balance models 518 combine a set of interrelated modules which include the following:

519 1) a behavioural model, to represent rainwater demand (D). Demand can be taken from literature, 520 historic meter data or real-time metering data;

521 2) a rainwater (R) inflow model to represent available water. This is based on synthetic rainfall series 522 or rain gauge data. Temporal datasets range from minutes to months with spatial proximity ranging 523 from on-site rain gauges to regional averages;

5243 3) a calculation module which enables tank mass balance simulations to be performed whilst 525 accounting for losses at each time step (such as roof runoff losses, first flush losses, filter losses, tank 526 overflows);

527 4) an output module which logs, summarises and presents data from each simulation.

528 The rainwater demand model represents user behaviour and this aspect is arguably the hardest aspect 529 to accurately quantify. Empirical datasets illustrate the stochastic nature (with high variability) of 530 water demands. Demand profiles can vary between seemingly identical households in similar 531 locations due to various socio-technical factors including varying work patterns, household 532 demographics and deployment of different water fittings (e.g. low-flush WCs). Behavioural model 533 tools have also been extended to include multiple concurrent demand patterns (e.g. toilet flushing, 
garden irrigation, etc.) (Campisano and Lupia, 2017). However, RWH evaluators frequently need to fix

535 the demand as an average value (usually average daily or monthly values) to enable simulations to be 536 carried out (Parker and Wilby, 2012; Ward et al., 2012; Melville-Shreeve et al., 2016). Sensitivity 537 analyses are required where behavioural models are based on a limited or uncertain data (Fewkes and 538 Butler, 2000). High resolution demand data may be needed to assure accurate outputs (Campisano 539 and Modica, 2015) depending on the objective of the analysis.

540 The rainwater inflow model must also account for significant input variability, which can be overcome 541 somewhat by using low resolution (spatially and temporally) regional averages. Model output accuracy can be improved by running simulations at higher frequencies (daily or sub-daily time steps), especially where site specific rainfall datasets are available (Ward et al., 2012). The accuracy of the results is also affected by the length of the available precipitation series. Although accuracy level is case-sensitive (i.e. affected by the local precipitation regime), various studies (e.g. Liaw and Tsai, 2004; Mitchell, 2007) agree that a 30-year long series should provide statistically reliable results. Calculation modules make use of various mass balance simulation schemes. Basic modelling approaches of "yield after spillage" (YAS) and "yield before spillage" (YBS) (Fewkes and Butler, 2000) have been used in many models in the context of RWH. Research studies have been devoted to the selection of the appropriate simulation time step to enable realistic representation of results of mass balances. Several authors (e.g. Fewkes and Butler, 2000; Mitchell, 2007;) analysed water saving efficiency by modelling a RWH system at a range of time intervals (hourly, daily and monthly) with the YAS and YBS operating rules tested. General conclusions support the use of the YAS operating algorithm for design purposes as it results in a more conservative estimate of water saving efficiency. With an increased focus on stormwater control, there is now an opportunity to revisit this work to evaluate the most conservative scenario under a dual purpose objective.

557 Water efficiency modelling approaches within RWH tools have been widely shown to give accurate 558 representations when daily time step intervals are used (e.g. Fewkes and Butler, 2000; Campisano et 559 al., 2013). However, RWH tools can be manipulated to use a wide range of time steps with selection 560 based on the resolution of data available. Recent work by Campisano and Modica $(2015,2016)$ has 
561 further exemplified the opportunity for high resolution (sub-hourly time steps) data to drive accurate

562 simulations, with specific emphasis on stormwater retention.

563 A range of studies which provide further details of existing RWH evaluation tools is described in Table

564 2. The selection of the most appropriate modelling tool and the simulation parameters depends on the objective of the analysis. Studies described in Table 2 suggest a trend towards increasing complexity and detail within RWH models. For example, Zhang et al. (2010) and a recent development within Campisano et al.'s (2012) tool enable stormwater management metrics to be generated. In addition, research identifying RWH water saving efficiencies in a wide range of international settings continues apace (Kim and Yoo, 2009; Ghisi and Schondermark, 2013; Karim et al., 2015; Unami et al., 2015).

In addition to satisfying local water demand, RWH is increasingly being considered as an option for contributing to stormwater management. Consequently, RWH evaluation tools have been further extended to enable stormwater management metrics to be evaluated (Kellagher and Maneiro Franco, 2007; Campisano and Modica, 2015; DeBusk et al., 2013). Gerolin et al. (2010) illustrated the ability of single tank RWH systems to capture stormwater runoff during extreme storms, noting that this was especially valid when $Q / D<1.0$, where $Q$ and $D$ are the yearly tank inflow volume and rainwater demand, respectively (see Fig. 1). Kellagher (2011) investigated these findings which contributed to revised stormwater source control guidance (now integrated within the British Standard BS8515) based on specifying oversized RWH tanks for properties where Q/D<0.95. Jensen et al.,(2010) have also shown that water saving and stormwater control are not conflicting objectives of RWH systems; however, different tank sizes are usually needed to obtain the optimal benefit for each objective.

Melville-Shreeve et al. (2014) illustrated the opportunity for dual purpose "retention and throttle" RWH systems to be designed and evaluated within proprietary drainage software. These findings showed that RWH systems for UK houses could be developed that provide $95 \%$ of the user's nonpotable water demand whilst also maintaining sufficient attenuation capacity to control stormwater runoff during the 1 in 100 year design storm. Mugume et al. (2016) extended this work to show how 
systems of this type can be deployed at a city scale to meet both stormwater and water efficiency

591 objectives.

592 Using life cycle analysis (LCA), Morales-Pinzón et al. (2015) have shown that the introduction of 593 environmental objectives (associated with emissions and the materials used) may impact significantly on tank sizing, depending on the type of the building in which the RWH system is installed.

\section{Financial viability}

There have been many studies that assessed the financial viability of RWH systems. Many of these studies make use of simple tools to match costs and benefits of system implementation. More recent tools based on an analysis of the system life cycle (Ward et al., 2012; Neto et al., 2012; Loubet et al., 2014; Morales-Pinzón et al., 2015) have also been used to assess benefits of RWH technologies 601 compared with alternative water supply strategies. Zhang et al. (2009) assessed the feasibility of RWH 602 in high-rise buildings in four capital cities in Australia and noted that Sydney has the shortest payback period (about 10 years) followed by Perth, Darwin and Melbourne. Analysis by Rahman et al. (2010) showed that payback in Sydney can be achieved for multi-storey buildings under some favourable scenarios and conditions (e.g. a low discount rate and a large number of users). Imteaz et al. (2011) showed that for large tanks connected to commercial roofs in Melbourne, the capital cost can be recovered within 15 to 21 years depending on the tank size and future water price increase rate. Various results have been obtained on the different level of viability of RWH systems with regard to the system size. Domènech and Saurí (2011) examined the efficiency of a RWH system for two main types of buildings (single and multi-family housing units) in Barcelona (Spain). They found that in

611 single-family households the payback period is in between 33 to 43 years depending on the tank size, 612 while for a multi-family building, it is larger than 60 years for a $20 \mathrm{~m}^{3}$ tank. Ghisi and Schondermark 613 (2013) found that domestic RWH in Santa Catarina State, Southern Brazil would be economically 614 feasible for most cases and generally the higher the rainwater demand, the higher the financial return. 615 In contrast, Roebuck et al. (2011) noted that domestic RWH systems in the UK are unlikely to deliver any realistic payback period given the assumptions made at the time. Ward et al. (2012) estimated, 
using empirical monitoring data, capital payback periods of between 6 and 11 years for a commercial-

618 scale office-based RWH system serving a building occupancy of 110 people.

619 It appears that a significant portion of researchers have found that RWH systems are not financially 620 viable, depending on scale (Kumar, 2004; Roebuck et al., 2011; Rahman et al., 2011). However, in 621 many cases, differences in the way maintenance and operational costs have been taken into account 622 (e.g. pump replacement, electricity bill and cleaning of roof catchment system) led to controversial 623 conclusions. For example, Ward et al. (2011) mentioned that using different evaluation methods can 624 determine differences up to $60 \%$ for energy consumption costs. Besides, most of the approaches utilised are simplistic as they do not holistically assess all potential benefits achievable with RWH systems. Indirect benefits such as savings due to delaying the upgrade of a major water infrastructure (water supply, sewer or treatment facility) (Coombes and Kuczera, 2003) or improved control of combined sewer overflows (Gwenzi and Nyamadzawo, 2014) are only two examples of benefits that 629 should be included for a more comprehensive and realistic analysis of the system return on 630 investment. Interestingly, Melville-Shreeve et al. (2014; 2016), using a Multiple Criteria Analysis, 631 demonstrated additional benefits of RWH such as energy savings and environmental benefits due to 632 reduced raw water abstraction, pumping, and water treatment. Other benefits may come from 633 increased agricultural efficiency in urban residential (food gardens) and rural contexts (Lupia and 634 Pulighe, 2015). Ngigi et al. (2005) found that a $50 \mathrm{~m}^{3}$ water tank for irrigation can increase the yield of 635 a 0.2 ha cropped land by $1000 \mathrm{~kg} / \mathrm{ha}$. Conversely, Fisher-Jeffes (2015) showed that implementing 636 RWH for water conservation and stormwater retention at the same time in a catchment would 637 negatively impact the economic viability of the system. Zhang et al. (2015) using Hedonic Price 638 Method showed that there is likely to be an increase in the real estate value of the homeowner's 639 property having a RWHS. Not least, hard water if replaced by rainwater (which is soft in nature) could 640 save washing costs (e.g. by reducing washing powder quantity) as noted by Morales-Pinzon et al. 641 (2014). 
Water price is one of the main governing factors of financial analysis of RWH systems (Morales-Pinzon 644 et al., 2015). To calculate benefit-cost ratio and payback periods, future water price needs to be 645 predicted. In this regard, future water price is expected to rise at a much faster rate than the general 646 interest rate. For example, during 2013-14, New South Wales and Victoria States in Australia experienced $27 \%$ and $24 \%$ increases in household water prices respectively (ABS, 2015). During this period, the inflation rate in Australia was in the range of 2.25 to $3 \%$ (TE, 2016). It is predicted that Melbourne's potable water price will increase by $100 \%$ within the next 5 years' time (Khastagir and Jayasurya, 2011). The second most important element in the financial analysis of a RWH system is the capital cost in relation to plumbing. For example, Amos et al. (2016) noted that plumbing cost may make the RWH system financially non-viable.

Finally, financial viability of RWH should also take into account that mains water in most countries is subsidized through direct and indirect measures (e.g. large capital funding of water supply reservoir construction by government money). Consequently, analogous subsidy/rebate based measures should be considered for appropriate comparative analysis with harvested rainwater, though approaches to this vary internationally (Ward et al., 2014).

661 Historically, challenges to the social acceptance of RWH (and indeed wider water reuse) have focused on water quality, risk perception and health risk, including the so-called 'yuck factor' (Fewtrell and 663 Kay, 2007b; Ward et al., 2010; Rozin et al., 2015), as well as financial viability (Roebuck et al., 2011). 664 As sections 4 and 6 of this paper highlight, knowledge to reduce the impact of these challenges has 665 been generated and for water quality at least, confidence built by recommendations to use risk 666 assessments and water safety plans (Gwenzi et al., 2015). Despite some households being resistant to 667 using rainwater indoors (Mankad et al., 2011), it is now acknowledged that RWH is an acceptable source of non-potable water compared to other types of water reuse for non-potable purposes 669 (Dobrowksy et al., 2014; Egyir et al., 2016). The focus on acceptability and financial returns to date has 
670 often detracted attention from wider challenges. These include evaluating social as well as financial

671 benefits to engender wider institutional support and reflexive analysis of the international RWH niche 672 to enable greater consideration of system efficacy and community participation, both of which will 673 enhance the hydrosocial contract and diffusion of RWH into wider society (Stenekes et al., 2006; 674 Getnet and MacAlister, 2012). Moving away from a rhetoric around perceptions and costs enables the 675 RWH sector to move towards a more positive and innovative space - where challenges are redefined 676 and responded to by policy-makers, businesses and communities.

7.1. Increasing institutional support through diverse benefit identification

679 As with approaches to water quality and quantity monitoring, government policy relating to and 680 institutional support for RWH is internationally variable. Brown and Keath (2008) assert (from an 681 Australian perspective) that facilitation of changes in practice can only occur if they are supported at 682 institutional and socio-political levels. For RWH in Australia, this would appear to be the case, as 683 growing water demand but restricted water availability catalysed State and Local Government funding 684 for RWH and, as a result, system penetration rates increased (White, 2011). As discussed in Section 3, 685 a similar shift has occurred in Japan after promotional supporting measures were introduced from the 686 early 1980s. The opposite case is demonstrated in the UK context by Parsons et al. (2010) who 687 highlight, through use of a questionnaire with house builders, that whilst knowledge about RWH has 688 increased, installation in practice, as well as institutional and regulatory gaps remain a challenge, as 689 does the lack of incentive schemes. The need to consider different charging mechanisms has been 690 highlighted, but to date no water service provider in England or Wales has adopted such a mechanism 691 (Ward et al., 2014).

693 Domènech and Saurí (2011) report that incentives coupled with complementary strategies are utilised 694 in Spain to stimulate installation, such as the introduction of local regulations (to mandate RWH in 695 new buildings) and partial subsidies (for new build and retrofit) requiring a voluntary contribution. 696 Consequently, it was hypothesized that citizens appreciating the benefits of RWH would be more likely 
to invest and apply for a subsidy, rather than the wider public - though it was found that the citizens

698 that did install RWH with a subsidy would have done so without.

The case is similar in the U.S.A., though different states have variable policies towards RWH as already discussed in Section 3. In Texas since 1993 six propositions or bills have passed through the legislative process directly pertaining to, in support of and incentivising RWH (such as manuals, awards, tax relief, exemptions, RWH committee establishment, state facilities directive, mandates and subsidies) (Ward et al., 2014). In a sub-catchment-scale example from the state of Ohio, the US Environmental Protection Agency implemented a novel reverse-auction incentive program to encourage citizens to install rain barrels and rain gardens in the Shepherd Creek watershed, Cincinnati. Enthusiasm for participation was generated by asking volunteers to bid and the lowest bidders would win and be offered compensation at that level. 174 rain barrels and 85 rain gardens were installed in two tranches, which were then subsequently monitored for hydrologic, water quality, ecological and enduser parameters, the latter of which was used to better understand the practices of rain barrel owners

711 (Shuster et al., 2013).

In Brazil the regulatory situation is somewhere in the middle, with some states imposing an obligation to include RWH in all new construction projects and others only imposing such a requirement if a roof area exceeds a certain level. However, in some areas RWH is unpopular due to resistance from water service providers citing lost revenue as their objection (Ward et al., 2014).

Inevitably different contexts require different approaches, but combinations of support actions are arguably more likely to enhance success. For example 'smart regulation' has been trialled and represents (for the German market) the interaction of three incentive schemes (water abstraction fees, water supply and effluent fees and subsidies), rather than their implementation in isolation (Partzsch, 2009). 
724 More recently, a range of methods, such as hedonic pricing and stated preference questionnaires, have 725 aimed to identify the social benefits RWH provides other than water savings, potential financial 726 savings and environmental kudos. Additional benefits may include feeling independent from the mains 727 water system, increasing property value and improving the life expectancy of local centralised 728 infrastructure (Zhang et al., 2015). However, further exploration of the applicability of other economic, 729 social-psychological and cultural methods is required to enable a more comprehensive identification 730 of other less tangible benefits. Highlighting these multiple benefits could represent a more 731 comprehensive approach to analysing the global status of RWH when combined with consideration of 732 the RWH niche as a whole, alongside technical relevance (system efficacy) and the extent to which end-users are engaged in the RWH process. These aspects are considered in the next section.

The application of a range of methods from outside the engineering toolkit, such as those previously mentioned, provides a stepping stone for the novel application of other techniques such as social network analysis (SNA). For example, to interrogate the UK RWH niche, Ward and Butler (2016) used SNA to develop a RWH network interaction model by mapping RWH actors and their relationships. The analysis showed that RWH infrastructure innovators were addressing challenges such as reducing energy use/carbon emissions and improving stormwater control by increasing the technical efficacy of their RWH products. This is in line with past research, such as that by White (2011) in the Australian context and Ward et al. (2011) for the UK, which highlighted the physical compatibility of the RWH with the household as a main issue for adoption suggesting a need for a broader portfolio of products addressing system configuration and increased flexibility. This gap was addressed by Melville-Shreeve et al. (2016) through a multi-criteria analysis of different system configurations representing a set of

Despite these technical innovations, innovation in service and social innovation by RWH infrastructure innovators and other organisations has been limited to date. This is beginning to change, however, as 
751 the effect of daily water-using practices of individuals on water availability comes into focus. This is 752 particularly true in developing countries where issues of gender arise, as water collection and management at the household level is often designated a female responsibility, whereas the construction of RWH storage tanks (cisterns) and community-level management of water often considered the domain of men (De Moraes and Rocha, 2013). By empowering women in the strategic and physical construction of water management in Brazil (One Million Cisterns RWH programme), they became both decision-makers and beneficiaries in relation to RWH (De Moraes and Rocha, 2013). Adler et al. (2014) emphasizes that community participation and leadership are also essential for the success of RWH programmes.

Three other social enterprise initiatives from across the globe include Mexico's Isla Urbana, India's public-community-private-partnership scheme Aakash Ganga and the UK's emerging RainShare (Isla Urbana, 2016; Sustainable Innovations, 2014). These initiatives support community participation in RWH by facilitating the installation of RWH systems to collectively share roof runoff from nearby houses. The households keep a proportion for their own use and the rest is channelled to a communal storage tank for various end-uses such as crop irrigation or household use. Each project has encountered a range of organisational and bureaucratic challenges to implementation. Some orientate around the layers of involvement of different organisations and groups concerned and others to the rigidity of institutional structures relating to existing infrastructure. Research into such issues that continues the theme of the application of novel methods is certainly warranted.

\section{Lessons learned and future research challenges}

773 Uptake from field application and experience gained from results of research in the recent decades 774 have provided some important lessons as well as identifying some areas of future research that would 775 contribute to advance the field of RWH.

776 Rainwater harvesting shows potential (to a varying extent) for applicability as an alternative approach to source water in cities across the world. In contrast to water-abundant developed countries, where 
RWH is prevalently considered as a backup supply source (Cook et al. 2013), very often systems for rainwater harvesting are a primary source of fresh water in several developing and drought-prone developed countries. Constraints such as local regulations and costs of implementation and maintenance play a key role in the system penetration rates and used technology in the various continents.

Consolidated confidence about the effectiveness of design protocols and water quality risk deriving from implementation of RWH systems has been achieved in recent decades. However, existing recommendations and guidelines typically consider system design in the perspective of water conservation/water saving objectives only, without taking into account a number of acknowledged additional benefits potentially achievable with RWH implementation. Increased research efforts in this direction are expected in the future in order to develop reliable multi-purpose model tools with greater connectivity to real systems for improved evaluation of RWH system global performance.

Research challenges could aim at including stormwater management metrics in RWH evaluators and at investigating interactions between RWH and the wider urban stormwater infrastructure. Although there has been a substantial amount of research internationally focused on RWH at a site scale, results concerning impacts at the regional scale in urban areas are very sparse. New approaches to focus on how to best represent RWH at larger scales need to be tested in different countries with different climatic conditions. Furthermore, more field data on RWH systems is required. There is a particular need to dedicate additional efforts to the monitoring of available pilot installations in order to improve quantification and types of rain water uses (sensu Umapathi et al., 2012). Evidence shows in fact that, new collective/private uses compatible with rainwater quality (e.g. irrigation for urban agriculture, fire suppression, infiltration for heat island mitigation, etc.) are quickly emerging with increased pressure on the available urban water budget.

801 Technology selection and regular maintenance are factors of paramount importance for the correct 802 functioning and the success of these systems as they assure appropriate water quality and improve 803 safety perception by users. In future, modelling should take into account the maintenance aspects of 804 RWH systems as such impacts could impact the quality of collected rainwater and its use. Indeed, 
research is required to better understand how tank maintenance can be encouraged. At the household

806 scale, Mankad et al. (2015) point to the use of information to empower tank owners to undertake 807 maintenance. Such information could take the form of pamphlets or be delivered through onsite 808 inspections, though further research into how building occupants actually live with RWH systems is 809 warranted in order to develop materials to best-engage end-users.

810 Financial viability of RWH systems seems far from being acceptable with payback periods still too high

811 to provide a suitable return on investment. However, actual financial models usually consider only 812 advantages in terms of drinking water conservation/saving, forgetting a number of non-secondary 813 benefits including system retention capability to reduce urban runoff. Consequently, future research is 814 expected to provide the streamlining of financial analysis of RWH systems including multiple 815 beneficial aspects under complex engineering, hydrological, economic and social settings. In this 816 context, a challenging task will be the development of approaches to quantify and include "soft" or less 817 tangible benefits such as amenity, placemaking, urban greening, urban cooling and the broad call for 818 water sensitive cities. Wider global environmental benefits or costs also need to be considered. It is 819 recognised that developments in technology and abundant uptake may reduce unit costs.

820 The development at a wider scale of RWH as sustainable approach for alternative water resource and 821 stormwater control requires improved support at institutional and socio-political levels aimed at 822 increasing incentive tools, awareness and societal acceptance.

823 In this sense, interdisciplinary research including socio-technical analysis to improve system efficacy 824 and community participation is required.

\section{Conclusions}

827 Based on the critical analysis developed in this paper, the following main conclusions may be drawn:

- Many existing RWH systems are focussed solely on the objective of conserving water without considering other potential benefits associated with the multi-purpose nature of RWH. 
- There is a lack of high quality datasets associated with the multiple objectives of RWH including especially: water saving, stormwater management, energy consumption and greenhouse gas emissions.

- $\quad$ There is a need for improved modelling of these multiple benefits.

- The role of satisfactory maintenance in system performance has been noted indicating the need for further research into how system reliability can be improved leading to increased system uptake.

- The financial evaluation of RWH shows widely varying results, mostly giving long payback figures. Greater consideration needs to be given to developing new, low-cost systems, especially for retrofit purposes.

- Incorporating multiple environmental benefits into the evaluation process, such as through Life Cycle Analysis, can improve overall economic viability of RWH depending on the specific context.

- The importance and influence of government policy and regulations has been highlighted, indicating the need for further research on how institutional and socio-political support can be best targeted to improve system efficacy and community acceptance. the state of the art of implementation of RWH systems in Japan.

\section{References}

Abbasi, T., Abbasi, S.A., 2011. Sources of Pollution in Rooftop Rainwater Harvesting Systems and Their Control. Critical Reviews in Environmental Science and Technology 41, 2097-2167.

Abdulla, F.A., Al-Shareef, A.W., 2009. Roof rainwater harvesting systems for household water supply in Jordan. Desalination 243, 195-207.

ABS, 2015. Water Account, Australia, 2013-14. http://www.abs.gov.au/ausstats/abs@.nsf/Latestproducts/4610.0Main\%20Features2201314 ?opendocument\&tabname $=$ Summary\&prodno $=4610.0$ \&issue $=2013-14 \&$ num $=\& v i e w=$. Accessed on 14 May 2016. 
Adeniyi, I.F., Olabanji, I.O., 2005. The physico-chemical and bacteriological quality of rainwater collected over different roofing materials in Ile-Ife, southwestern Nigeria. Chemistry and Ecology 21, 149-166.

Adler, I., Campos, L., Bell, S., 2014. Community participation in decentralised rainwater systems: a Mexican case study. Chapter 6 In: Memon, F.A., Ward, S. Alternative Water Supply Systems. IWA Publishing, London, eISBN: 9781780405513.

Akoto, O., Appiah, F., Boadi, N.O., 2011. Physicochemical analysis of roof runoffs from the Obuasi Area. Water Practice and Technology, 6(1), doi: 10.2166/wpt.2011.003.

Albrechtsen, H.J., 2002. Microbiological investigations of rainwater and graywater collected for toilet flushing. Water Science and Technology 46, 311-316.

Amos, C.C., Rahman, A., Gathenya, J.M., 2016. Economic Analysis and Feasibility of Rainwater Harvesting Systems in Urban and Peri-Urban Environments: A Review of the Global Situation with a Special Focus on Australia and Kenya. Water 8(4), 149.

An, K.J., Lam, Y.F., Hao, S., Morakinyo, T.E., Furumai, H., 2015. Multi-purpose rainwater harvesting for water resource recovery and the cooling effect. Water Research 86, 116-121.

Angrill, S., Farreny, R., Gasol, C.M., Gabarrell, X., Viñolas, B., Josa, A., Rieradevall, J., 2012. Environmental analysis of rainwater harvesting infrastructures in diffuse and compact urban models of Mediterranean climate. International Journal of Life Cycle Assessment 17(1), 25-42.

Basinger, M., Montalto, F., Lall, U., 2010. A rainwater harvesting system reliability model based on nonparametric stochastic rainfall generator. Journal of Hydrology 392, 105-118.

Bradford, A., Denich, C., 2007. Rainwater management to mitigate the effects of development on the urban hydrologic cycle. Journal of Green Building 2, 37-52.

Briggs, J., Reidy, P., 2010. Advanced Water Budget Analysis for Rainwater and Related Harvesting Applications. World Environmental and Water Resources Congress 2010: pp. 475-484. DOI: 10.1061/41114(371)53.

British Standards Institute, 2013. Rainwater harvesting systems - Code of practice BS 8515:2009+A1:2013.

Brodie, I.M., 2008. Hydrological analysis of single and dual storage systems for stormwater harvesting. Water Science and Technology 58, 1039-1046.

Brown, R., Keath, N., 2008. Drawing on social theory for transitioning to sustainable urban water management: turning the institutional super-tanker. Australian Journal of Water Resources 12(2), $1-12$.

Burns, M.J., Fletcher, T.D., Duncan, H.P., Hatt, B.E., Ladson, A.R., Walsh, C.J., 2015. The performance of rainwater tanks for stormwater retention and water supply at the household scale: an empirical study. Hydrological Processes 29(1), 152-160.

Burns, M.J., Fletcher, T.D., Duncan, H.P., Landson, A.R., Walsh, C.J., 2012a. The stormwater retention performance of rainwater tanks at the land-parcel scale. In: Wong, T.H.F., McCarthy, D.T. (eds.), 7th International Conference on Water Sensitive Urban Design. Engineers Australia, Melbourne, Australia, 2012.

Burns, M.J., Fletcher, T.D., Walsh, C.J., Landson, A.R., Hatt, B.E., 2012b. Hydrologic shortcomings of conventional urban stormwater management and opportunities for reform. Landscape and Urban Planning 105, 230-240.

Campisano, A., Gnecco, I., Modica, C., Palla, A., 2013. Designing domestic rainwater harvesting systems under different climatic regimes in Italy. Water Science and Technology 67(11), 2511-2518.

Campisano, A., Lupia, F., 2017. A dimensionless approach for water saving evaluation of domestic rainwater harvesting for toilet flushing and food garden irrigation in urban areas. Urban Water Journal (in press).

Campisano, A., Modica, C., 2012. Regional scale analysis for the design of storage tanks for domestic rainwater harvesting systems. Water Science and Technology 66(1), 1-8.

Campisano, A., Modica, C., 2015. Appropriate resolution timescale to evaluate water saving and retention potential of rainwater harvesting for toilet flushing in single houses. Journal of Hydroinformatics 17(3), 331-346

Campisano, A., Modica, C., 2016. Rainwater harvesting as source control option to reduce roof runoff peaks to downstream drainage systems. Journal of Hydroinformatics 18(1), 23-32. 
Chang, M., Crowley, C.M., 1993. Preliminary observations on water quality of storm runoff from four selected residential roofs. Journal of the American Water Resources Association 29, 777-783.

Chang, M., McBroom, M.W., Scott Beasley, R., 2004. Roofing as a source of nonpoint water pollution. Journal of Environmental Management 73, 307-315.

Clark, S., Steele, K., Spicher, J., Siu, C., Lalor, M., Pitt, R., Kirby, J., 2008. Roofing materials' contributions to storm-water runoff pollution. Journal of Irrigation and Drainage Engineering 134, 638-645.

Cook, S., Sharma, A., Chong, M., 2013. Performance analysis of a communal residential rainwater system for potable supply: A case study in Brisbane, Australia. Water Resource Management 27, 4865-4875.

Coombes, P.J., Kuczera, G., 2003. A sensitivity analysis of an investment model used to determine the economic benefits of rainwater tanks. Proc. 28th International Hydrology and Water Resources Symposium, Wollongong, Australia, 243-250.

Coutts, A.M., Tapper, N.J., Beringer, J., Loughnan, M., Demuzere, M., 2012. Watering our Cities: The capacity for Water Sensitive Urban Design to support urban cooling and improve human thermal comfort in the Australian context. Progress in Physical Geography 37(1), 2-28.

Cowden, J.R., Watkins, D.W., Mihelcic, J.R., 2008. Stochastic modeling in West Africa: parsimonius approaches for domestic rainwater harvesting assessment. J. Hydrol. 361, 64-77

Crabtree, K.D., Ruskin, R.H., Shaw, S.B., Rose, J.B., 1996. The detection of Cryptosporidium oocysts and Giardia cysts in cistern water in the U.S. Virgin Islands. Water Research 30, 208-216.

Dao, A.D., Han, M.N., Guyen, V.A., Ho, X.Q., Kim, T.H., 2009. Flooding Mitigation Plan at Downtown of Hanoi by Rainwater Harvesting. Proceedings of the 8th International Conference on Urban Drainage Modelling and 2nd International Conference on Rainwater Harvesting and Management., The University of Tokio, Tokyo, Japan.

Debusk, K. M., Hunt, W.F., 2014. Rainwater Harvesting: A Comprehensive Review of Literature. Water Resources Research Institute of the University of North Carolina, Report n. 425, 2014-02.

Debusk, K.M., Hunt, W.F., Wright, J.D., 2013. Characterizing rainwater harvesting performance and demonstrating stormwater management benefits in the humid southeast USA. Journal of the American Water Resources Association 49, 1398-1411.

De Gouvello, B., Gerolin, A., Le Nouveau, N., 2014. Rainwater harvesting in urban areas: How can foreign experiences enhance the French approach? Water Science and Technology: Water Supply 14(4), 569-576.

De Moraes, A.F.J., Rocha, C., 2013. Gendered waters: the participation of women in the 'One Million Cisterns' rainwater harvesting program in the Brazilian Semi-Arid region. Journal of Cleaner Production 60, 163-169.

Despins, C., Farahbakhsh, K., Leidl, C., 2009. Assessment of rainwater quality from rainwater harvesting systems in Ontario, Canada. Journal of Water Supply: Research and Technology - Aqua $58,117-134$.

Deutsches Institut für Normung, 1989. DIN 1989 part 1-3. Regulation of requirements for rainwater harvesting systems.

Devkota, J., Schlachter, H., Apul, D., 2015. Life cycle based evaluation of harvested rainwater use in toilets and for irrigation. Journal of Cleaner Production 95, 311-321.

Dillon, P., 2005. Future management of aquifer recharge. Hydrogeol. J. 13(1), 313-316.

Dixon, A., Butler, D., Fewkes, A., 1999. Water saving potential of domestic water reuse systems using greywater and rainwater in combination. Water Science and Technology 39, 25-32.

Dobrowksy, P.H., Mannel, D., Kwaadsteniet, M., Prozesky, H., Khan, W., Cloete, T.E., 2014. Quality assessment and primary uses of harvested rainwater in Kleinmond, South Africa. WaterSA 40(3), 401-406.

Domènech, L., Saurí, D., 2011. A comparative appraisal of the use of rainwater harvesting in single and multi-family buildings of the Metropolitan Area of Barcelona (Spain): social experience, drinking water savings and economic costs. Journal of Cleaner Production 19(6-7), 598-608.

Egyir, S.N., Brown, C., Arthur, S., 2016. Rainwater as a domestic water supplement in Scotland: attitudes and perceptions. British Journal of Environment and Climate Change 6(3), 160-169. 
Farreny, R., Morales-Pinzón, T., Guisasola, A., Tayà, C., Rieradevall, J., Gabarrell, X., 2011. Roof selection for rainwater harvesting: Quantity and quality assessments in Spain. Water Research 45(10), 3245-3254.

Fewkes, A., Butler, D., 2000. Simulating the performance of rainwater collection systems using behavioural models. Building Services Engineering Research and Technology 21(2), 99-106.

Fewtrell, L., Kay, D., 2007a. Quantitative microbial risk assessment with respect to Campylobacter spp. in toilets flushed with harvested rainwater. Water and Environment Journal 21(4), 275-280.

Fewtrell, L., Kay, D. 2007b. Microbial quality of rainwater supplies in developed countries: a review. Urban Water Journal 4, 253-260.

Fisher-Jeffes, L.N., 2015. The viability of rainwater and stormwater harvesting in the residential areas of the Liesbeek River Catchment, Cape Town. (PhD Thesis), University of Cape Town, South Africa. Available, at: http://open.uct.ac.za/discover?filtertype=type\&filter_relational_operator=equals\&query=fisherJeffes\&filter $=$.

Förster, J., 1999. Variability of roof runoff quality. Water Science and Technology 39, 137-144.

Furumai, 2008. Rainwater and reclaimed wastewater for sustainable urban water use.Physics and Chemistry of the Earth, Parts A/B/C 33(5), 340-346.

Gardner, T., Vieritz, A., 2010. The role of rainwater tanks in Australia in the twenty first century. Architectural Science Review 53, 107-125.

Gee, K., Hunt, W., 2016. Enhancing stormwater management benefits of rainwater harvesting via innovative technologies. Journal of Environmental Engineering 142(8), doi: 10.1061/(ASCE)EE.1943-7870.0001108..

Gerolin, A., Kellagher, R.B., Faram, M.G., 2010. Rainwater harvesting systems for stormwater management: Feasibility and sizing considerations for the UK. Proceedings of $7^{\text {th }}$ International Conference on Sustainable Techniques and Strategies in Urban Water Management - NOVATECH 2010, Graie, Lyon, 2010.

Getnet, K., MacAlister, C., 2012. Integrated innovations and recommendation domains: paradigm for developing, scaling-out, and targeting rainwater management innovations. Ecological Economics 76, 34-41.

GhaffarianHoseini, A., Tookey, J., GhaffarianHoseini, A., Yusoff, S.M., Hassan, N.B., 2016. State of the art of rainwater harvesting systems towards promoting green built environments: a review, Desalination and Water Treatment 57(1), 95-104.

Ghisi, E., 2010. Parameters influencing the sizing of rainwater tanks for use in houses. Water Resources Management 24(10), 2381-2403.

Ghisi, E., Schondermark, P.N., 2013. Investment Feasibility Analysis of Rainwater Use in Residences. Water Resources Management 27, 2555-2576.

Godskesen, B., Hauschild, M., Rygaard, M., Zambrano, K., Albrechtsen, H.J., 2013. Life-cycle and freshwater withdrawal impact assessment of water supply technologies. Water Research 47(7), 2363-2374.

Gomes, U.A.F., Heller, L., Pena, J.L., 2012. A National Program for Large Scale Rainwater Harvesting: An Individual or Public Responsibility? Water Resources Management 26, 2703-2714.

Gould, J., 1993. A review of the development, current status and future potential of rainwater catchment systems for household supply in Africa. Proceedings of the 6th International Conference on Rainwater Catchment Systems, p. 10, IRCSA, Nairobi.

Gould, J., Zhu, Q., Yuanhong, L., 2014. Using every last drop: Rainwater harvesting and utilization in Gansu Province, China. Waterlines 33(2), 107-119.

Guo, Y., Baetz, B.W., 2007. Sizing of Rainwater Storage Units for Green Building Applications. Journal of Hydrologic Engineering. doi:10.1061/(ASCE)1084-0699(2007)12:2(197).

Gwenzi, W., Nothando, D., Pisa, C., Tauro, T., Nyamadzawo, G., 2015. Water quality and public health risks associated with roof rainwater harvesting systems for potable supply: review and perspectives. Sustainability of Water Quality and Ecology 6, 107-118.

Gwenzi, W., Nyamadzawo, G., 2014. Hydrological impacts of urbanization and urban roof water harvesting in water-limited catchments: A review. Environmental Processes 1, 573-593. 
1021

1022

1023

1024

1025

1026

1027

1028

1029

1030

1031

1032

1033

1034

1035

1036

1037

1038

1039

1040

1041

1042

1043

1044

1045

1046

1047

1048

1049

1050

1051

1052

1053

1054

1055

1056

1057

1058

1059

1060

1061

1062

1063

1064

1065

1066

1067

1068

1069

1070

1071

1072

1073

1074

Hamdan, S.M., 2009. A literature based study of stormwater harvesting as a new water resource. Water Science and Technology 60, 1327-1339.

Hamel, P., Fletcher, T.D., 2014. The impact of stormwater source-control strategies on the (low) flow regime of urban catchments. Water Science and Technology 69(4), 739-745.

Hamel, P., Fletcher, T.D., Daly, E., Beringer, J., 2012. Water retention by raingardens: implications for local-scale soil moisture and water fluxes. In: Wong, T.H.F., McCarthy, D.T. (eds.) 7th International Conference on Water Sensitive Urban Design, Engineers Australia, Melbourne, Australia, 2012.

Han M.Y., Mun J.S., 2011. Operational data of the Star City rainwater harvesting system and its role as a climate change adaptation and a social influence. Water Science and Technology 63(12), 2796801.

Handia, L., Tembo, J.M., Mwiindwa, C., 2003. Potential of rainwater harvesting in urban Zambia. Physics and Chemistry of the Earth, Parts A/B/C, 28(20-27), 893-896.

Hardie, M., 2010. Rainwater storage gutters for houses. Sustainability 2, 266-279.

Hermann, T., Schmida, U., 2000. Rainwater utilisation in Germany: efficiency, dimensioning, hydraulic and environmental aspects. Urban Water 1, 307-316.

Imteaz, M.A., Shanableh, A., Rahman, A., Ahsan, A., 2011. Optimisation of Rainwater Tank Design from Large Roofs: A Case Study in Melbourne, Australia. Resources, Conservation and Recycling 55, 1022-1029.

Isla Urbana, 2016. Isla Urbana. http://islaurbana.org/english/. Accessed 18-02-16

Iveroth, S. P., Johansson, S. and Brandt, N., 2013. The potential of the infrastructural system of Hammerby Sjöstad in Stockholm, Sweden. Energy Policy 59, 716-726.

Jensen, M.A., Steffen, J., Burian, S.J., Pomeroy, C., 2010. Do rainwater harvesting objectives of water supply and stormwater management conflict? Low Impact Development 2010: Redefining Water in the City - Proceedings of the 2010 International Low Impact Development Conference, pp. 1120, ASCE, USA, ISBN: 9780784410998.

Jiang, Z., Li, X., Ma, Y., 2013. Water and Energy Conservation of Rainwater Harvesting System in the Loess Plateau of China. Journal of Integrative Agriculture 12(8), 1389-1395

Jones, M.P., Hunt, W.F., 2010. Performance of rainwater harvesting systems in the southeastern United States. Resources, Conservation and Recycling 54, 623-629.

Karim, M.R., Bashar, M.Z.I., Imteaz, M.A., 2015. Reliability and economic analysis of urban rainwater harvesting in a megacity in Bangladesh. Resources, Conservation and Recycling 104, Part A, 61-67.

Kellagher, R., 2011. SR732. Stormwater Management using Rainwater Harvesting. Report SR 732, HR Wallingford, UK, 2011.

Kellagher, R., Maneiro Franco, E., 2007. Rainfall collection and use in developments; benefits for yield and stormwater control. WaND Briefing Note 19, Report SR 677, HR Wallingford, UK, 84, 2007.

Khastagir A., Jayasuriya N., 2011. Investment evaluation of rainwater tanks. Water Resour. Manage. 25, 3769-84.

Kim, K., Yoo, C., 2009. Hydrological modeling and evaluation of rainwater harvesting facilities: case study on several rainwater harvesting facilities in Korea. Journal of Hydrologic Engineering 14, 545-561.

Kollo, M., Laanearu, J., 2015. An optimal solution of thermal energy usage in the integrated system of stormwater collection and domestic-water heating. Urban Water Journal, doi: 10.1080/1573062X.2015.1086006.

Kumar, M.D., 2004. Roof water harvesting for domestic water security: Who gains and who loses? Water International 29, 43-53.

Kus, B., Kandasamy, J., Vigneswaran, S., Shon, H.K., 2010a. Analysis of first flush to improve the water quality in rainwater tanks. Water Science and Technology 61, 421-428.

Kus, B., Kandasamy, J., Vigneswaran, S., Shon, H.K., 2010b. Water quality characterisation of rainwater in tanks at different times and locations. Water Science and Technology 61, 429-439.

Lash, D., Ward, S., Kershw, T., Butler, D., Eaames, M., 2014. Robust rainwater harvesting: probabilistic tank sizing for climate change adaptation. Journal of Water and Climate Change 5, 526-539.

Lee, J.Y., Yang, J.S., Han, M., Choi, J., 2010. Comparison of the microbiological and chemical characterization of harvested rainwater and reservoir water as alternative water resources. Science of The Total Environment 408, 896-905. 
1075

1076

1077

1078

1079

1080

1081

1082

1083

1084

1085

1086

1087

1088

1089

1090

1091

1092

1093

1094

1095

1096

1097

1098

1099

1100

1101

1102

1103

1104

1105

1106

1107

1108

1109

1110

1111

1112

1113

1114

1115

1116

1117

1118

1119

1120

1121

1122

1123
Liaw, C.H., Tsai, Y.L., 2004. Optimum storage volume of rooftop rainwater harvesting systems for domestic use. J. Am. Water Resour. Assoc. 40, 901-12

Lizárraga-Mendiola, L., Vázquez-Rodríguez, G., Blanco-Piñón, A., Rangel-Martínez, Y., GonzálezSandoval, M., 2015. Estimating the Rainwater Potential per Household in an Urban Area: Case Study in Central Mexico. Water 7(9), 4622-4637.

Loubet, P., Roux, P., Loiseau, E., Bellon-Maurel, V., 2014. Life cycle assessments of urban water systems: A comparative analysis of selected peer-reviewed literature. Water Research 67, 187-202.

Lupia, F., Pulighe, G., 2015. Water Use and Urban Agriculture: Estimation and water saving scenarios for residential kitchen gardens. Agriculture and Agricultural Science Procedia 4, 50-58.

Lye, D., 2002. Health risks associated with consumption of untreated water from household roof catchment systems. Journal of the American Water Resources Association 38(5), 1301-1306.

Magyar, M.I., Mitchell, V.G., Ladson, A.R., Diaper, C., 2007. An investigation of rainwater tanks quality and sediment dynamics. Water Science and Technology 56, 21-28.

Mankad, A., Fielding, K., Tapsuwan, S., 2015. Chapter 8: Public perceptions, motivational drivers, and maintenance behaviour for urban rainwater tanks. In A. K. Sharma, D. Begbie \& T. Gardiner (Eds.), Rainwater tank systems for urban water supply. London, United Kingdom: IWA Publishing.

Mankad, A., Tapsuwan, S., 2011. Review of socio-economic drivers of community acceptance and adoption of decentralised water systems. Journal of Environmental Management 92(3), 380-391. doi: 10.1016/j.jenvman.2010.10.037.

Marcynuk, P.B., Flint, J.A., Sargeant, J.M., Jones-Bitton, A., Brito, A.M., Luna, C.F., Szilassy, E., Thomas, M.K., Lapa, T.M., Perez, E., Costa, A., 2013. Comparison of the burden of diarrhoeal illness among individuals with and without household cisterns in northeast Brazil. BMC Infectious Diseases 2013, 13-65; http://www.biomedcentral.com/1471-2334/13/65

Martin, A.R., Coombes, P.J., Dunstan, R.H., 2010. Investigating the influences of season and coastal proximity on the elemental composition of harvested rainwater. Water Science and Technology 61, 25-36.

Master Plumbers and Mechanical Services Association of Australia, 2008. Rainwater Tank Design and Installation Handbook. Australian Government National Water Commission.

Mati, B., Bock, T. Malesu, M., Khaka, E., Oduor, A., Nyabenge, M., Oduor, V., 2006. Mapping the Potential of Rainwater Harvesting Technologies in Africa: A GIS overview on development domains for the continent and ten selected countries, Technical Manual n. 5. (accessed 7/2/2017) http://worldagroforestrycentre.net/downloads/publications/PDFs/MN15297.PDF.

Meera, V., Ahammed, M.M., 2008. Solar disinfection for household treatment of roof-harvested rainwater. Water Science and Technology: Water Supply 8, 153-160.

Melidis, P., Akratos, C.S., Tsihrintzis, V.A., Trikilidou, E., 2007. Characterization of rain and roof drainage water quality in Xanthi, Greece. Environmental Monitoring and Assessment 127, 15-27.

Melville-Shreeve, P. Ward, S., Butler, D., 2014. Developing a methodology for appraising rainwater harvesting with integrated source control using a case study from south-west England. Proceedings of $13^{\text {th }}$ International conference on Urban Drainage (ICUD2014), Kuching, Malaysia, IWA Publishing, UK, 2014.

Melville-Shreeve, P., Ward, S., Butler, D., 2016. Rainwater Harvesting Typologies for UK Houses: A Multi Criteria Analysis of System Configurations. Water 8, 129.

Mendez, C.B., Klenzendorf, J.B., Afshar, B.R., Simmons, M.T., Barrett, M.E., Kinney, K.A., Kirisits, M.J., 2011. The effect of roofing material on the quality of harvested rainwater. Water Research 45, 2049-2059.

MI, 2013. Architecture and Building Research Institute. Evaluation Manual for Green Buildings in Taiwan, Ministry of Interior Taipei, Taiwan (in Chinese).

Mitchell, V., 2007. How important is the selection of computational analysis method to the accuracy of rainwater tank behavior modelling? Hydrological Processes 21, 2850-2861.

MLIT, 2014. Water Resources in Japan 2014 (in Japanese). http://www.mlit.go.jp/mizukokudo/mizsei/mizukokudo mizsei fr2 000012.html._ (accessed $\underline{7 / 2 / 2017) \text {. }}$ 
1124

1125

1126

1127

1128

1129

1130

1131

1132

1133

1134

1135

1136

1137

1138

1139

1140

1141

1142

1143

1144

1145

1146

1147

1148

1149

1150

1151

1152

1153

1154

1155

1156

1157

1158

1159

1160

1161

1162

1163

1164

1165

1166

1167

1168

1169

1170

1171

1172

1173

1174

1175

1176
Morales-Pinzón, T., Lurueña, R., Gabarrell, X., Gasol, C.M., Rieradevall, J., 2014. Financial and environmental modelling of water hardness - Implications for utilising harvested rainwater in washing machines. Science of the Total Environment 470-471, 1257-1271.

Morales-Pinzón, T., Rieradevall, J., Gasol, C.M., Gabarrell, X., 2015. Modelling for economic cost and environmental analysis of rainwater harvesting systems. Journal of Cleaner Production 87(2015), 613-626.

Morrow, A.C., Dunstan, R.H., Coombes, P.J., 2010. Elemental composition at different points of the rainwater harvesting system. Science of the Total Environment 408, 4542-4548.

Mugume, S., Melville-Shreeve, P., Gomez, D., Butler, D., 2016. Multifunctional urban flood resilience enhancement strategies. Water Management, doi: 10.1680/jwama.15.00078.

Neto, R.F.M., de Castro Carvalho, I., Calijuri, M.L., da Fonseca Santiago, A., 2012. Rainwater treatment in airports using slow sand filtration followed by chlorination: Efficiency and costs. Resources, Conservation and Recycling 65, 124-129.

Ngigi, S.N., Savenije, H.H., Rockström, J., Gachene, C.K., 2005. Hydro-economic evaluation of rainwater harvesting and management technologies: Farmers' investment options and risks in semi-arid laikipia district of Kenya. Phys. Chem. Earth Parts A/B/C 30, 772-782.

Olem, H., Berthouex, P.M., 1989. Acidic deposition and cistern drinking water supplies. Environmental Science and Technology 23, 333-340.

Palla, A., Gnecco, I., Lanza, L.G., 2011. Non-dimensional design parameters and performance assessment of rainwater harvesting systems. Journal of Hydrology 401(1-2), 65-76.

Parker, J.M., Wilby, R.L., 2012. Quantifying Household Water Demand: A Review of Theory and Practice in the UK. Water Resour Manage 27(2013), 981-1011.

Parkes, C., Kershaw, H., Hart J., Sibille, R., Grant, Z., 2010. Energy and Carbon Implications of Rainwater Harvesting \& Greywater Recycling. Final Report, Science Project Number: SC090018, Environment Agency, Bristol. http://publications.environmentagency.gov.uk/pdf/SCHO0610BSMQ-e-e.pdf.

Parsons, D., Goodhew, S., Fewkes, A., De Wilde, P., 2010. The perceived barriers to the inclusion of rainwater harvesting systems by UK house building companies. Urban Water 7(4), 257-265.

Partzsch, L., 2009. Smart regulation for water innovation - the case of decentralized rainwater technology. Journal of Cleaner Production 17, 985-991.

Quek, U., Förster, J., 1993. Trace metals in roof runoff. Water, Air, and Soil Pollution 68, 373-389.

Rahman, A., Dbais, J., Imteaz, M., 2010. Sustainability of rainwater harvesting systems in multistory residential buildings. American Journal of Engineering and Applied Sciences 3(1), 889-898.

Rahman, A., Dbais, J., Mitchell, C., Ronaldson, P., Shrestha, S., 2011. Study of rainwater tanks as a source of alternative water supply in a multistory residential building in Sydney, Australia. In: Kabbes, K (ed.), Proceedings of the World Environmental and Water Resources Congress, Environmental and Water Resources 2007, ASCE, USA, ISBN: 9781604233063.

Ringelstein, O., 2015. Now we can shower with Rain Water. GWF, Wasser - Abwasser 156, 58-61.

Roebuck, R.M., 2008. A Whole life costing approach for rainwater harvesting systems: An investigation into the whole life cost implications of using rainwater harvesting systems for non-potable applications in new-build developments in the UK, PhD Thesis.

Roebuck, R.M., Oltean-Dumbrava, C., Tait, S., 2011. Whole life cost performance of domestic rainwater harvesting systems in the United Kingdom. Water and Environment Journal 25(3), 355-365.

Rozin, P., Haddad, B., Nemeroff, C., Slovic, P., 2015. Psychological aspects of the rejection of recycled water: contamination, purification and disgust. Judgement and Decision Making 10(1), 50-63.

Sazakli, E., Alexopoulos, A., Luotsinidis, M., 2007. Rainwater harvesting, quality assessment and utilization in Kefalonia Island, Greece. Water Research 41, 2039-2047.

Sample, D.J., Liu, J., 2014. Optimizing rainwater harvesting systems for the dual purposes of water supply and runoff capture. J. Cleaner Prod. 75, 174-194

Schets, F.M., Italiaander, R., Van Den Berg, H.H.J.L., De Roda Husman, A.M., 2010. Rainwater harvesting: quality assessment and utilization in The Netherlands. Journal of Water and Health 8, 224-235.

Schuetze, T., 2013. Rainwater harvesting and management - Policy and regulations in Germany. Water Science and Technology: Water Supply 13(2), 376-385 
1177

1178

1179

1180

1181

1182

1183

1184

1185

1186

1187

1188

1189

1190

1191

1192

1193

1194

1195

1196

1197

1198

1199

1200

1201

1202

1203

1204

1205

1206

1207

1208

1209

1210

1211

1212

1213

1214

1215

1216

1217

1218

1219

1220

1221

1222

1223

1224

1225

1226

1227

1228

Shuster, W. D., Lye, D., De La Cruz, A., Rhea, L., K., O'Connell, K., Kelty, A., 2013. Assessment of residential rain barrel water quality and use in Cincinnati, Ohio. Journal of the American Water Resources Association, 49 (4), 753-765.

Simmons, G., Hope, V., Lewis, G., Whitmore, J., Gao, W., 2001. Contamination of potable roof-collected rainwater in Auckland, New Zealand. Water Research 35, 1518-1524.

Steffen, J., Jensen, M., Pomeroy, C.A., Burian, S.J., 2012. Water supply and stormwater management benefits of residential rainwater harvesting in U.S. cities. Journal of the American Water Resources Association 49(4), 810-824.

Stenekes, N., Colebatch, H.K., Waite, D.T., Ashbolt, N.J., 2006. Risk and governance in water recycling: public acceptance revisited. Science, Technology and Human Values 31(2), 107-134.

Sung, M., Kan, C.C., Wan, M.W., Yang, C.R., Wang, J.C., Yu, K.C., Lee, S.Z., 2010. Rainwater harvesting in schools in Taiwan: system characteristics and water quality. Water Science and Technology 61, 1767-1778.

Sustainable Innovations, 2014. Executive summary: Aakash Ganga implementation - proposal to Government of Rajasthan \& investors for drinking water \& garden irrigation in 50-100 villages. http://www.sustainableinnovations.org/Water Catchment for Arid Areas files/Executive\%20Su mmary\%20Aakash\%20Ganga\%20S\%20copy.pdf. Accessed 18-02-16

Taffere, G.R., Beyene, A., Vuai, S.A.H., Gasana, J., Seleshi, Y., 2016. Dilemma of roof rainwater quality: applications of physical and organic treatment methods in a water scarce region of Mekelle, Ethiopia. Urban Water Journal, doi: 10.1080/1573062X.2016.1176225.

TE, 2016. Australian Inflation Rate, Trading Economics, Accessed on 31 Oct 2016 at: http://www.tradingeconomics.com/australia/inflation-cpi.

Texas Water Development Board, 2005. The Texas Manual on Rainwater Harvesting. 3rd Edition, Austin

Texas,

www.twdb.texas.gov/publication/brochures/conservation/doc/RainwaterHarvestingManual 3rd edition.pdf. (accessed 7/2/2017).

Thomas, P.R., Greene, G.R., 1993. Rainwater quality from different roof catchments. Water Science and Technology 28, 291-299.

Umapathi, S., Chong, M.N., Sharma, A., 2012. Investigation and monitoring of twenty homes to understand mains water savings from mandated rainwater tanks in south east Queensland. Urban Water Security Research Alliance Technical Report No. 63, Urban Water Security Research Alliance. URL: http://www.urbanwateralliance.org.au/publications/technicalreports/ (accessed April 2016).

Unami, K., Mohawesh, O., Sharifi, E., Takeuchi, J., Fujihara, M., 2015. Stochastic modelling and control of rainwater harvesting systems for irrigation during dry spells. Journal of Cleaner Production 88, 185-195.

UNI, 2012. Norme tecniche per la progettazione, installazione e manutenzione degli impianti per la raccolta e utilizzo dell'acqua piovana per usi diversi dal consumo umano, UNI/TS 11445:2012 (in Italian).

Vialle, C., Sablayrolles, C., Lovera, M., Jacob, S., Huau, M.C., Montrejaud-Vignoles, M., 2011. Monitoring of water quality from roof runoff: interpretation using multivariate analysis. Water Research 45, 3765-3775.

Vieira, A. S., Ghisi, E., Weeber, M., 2013. Self-cleaning filtration: A novel concept for rainwater harvesting systems. Resources, Conservation and Recycling 78, 67-73.

Vieritz, A., Gardner, T., Baisden, J., 2007. Rainwater tank model designed for use by urban planners. Proceedings of the Australian Water Association's Ozwater Convention and Exhibition. 4-8 March 2007, Sydney. (CD). ISBN 978-0-908255-67-2.

Yaziz, M.I., Gunting, H., Sapari, N., Ghazali, A.W., 1989. Variations in rainwater quality from roof catchments. Water Research 23, 761-765.

Yufen, R., Xiaoke, W., Zhiyun, O., Hua, Z., Xiaonan, D., Hong, M., 2008. Stormwater runoff quality from different surfaces in an urban catchment in Beijing, China. Water Environment Research 80, 719724. 
Waller, D.H., Armijos-Luna, E., Scott, R.S., 2001. Potential of Rainwater Cistern Systems for Bluefields, Nicaragua. 10th International Rainwater Catchment Systems Conference. Mannheim, Germany, 2001. Available at http://www.eng.warwick.ac.uk/ircsa/pdf/10th/2 01.pdf

Ward, S., Butler, S., 2016. Rainwater Harvesting and Social Networks: Visualising Interactions for Niche Governance, Resilience and Sustainability. Water 8 (11), 526-551, doi:10.3390/w8110526.

Ward, S., Butler, D., Daly, B., Deegan, A.M., Maganha de Almeida, A.C. and Lennox, I., 2017 Alleviating health risks associated with rainwater harvesting. Journal of Environmental Engineering and Science (accepted).

Ward, S., Butler, D., Memon, F., 2011. Benchmarking energy consumption and CO2 emissions from rainwater harvesting systems: an improved method by proxy. Water and Environment Journal 26(2), 184-190. doi: 10.1111/j.1747-6593.2011.00279.x

Ward, S., Dornelles, F., Giacomo, M.H., 2014. Incentivising and charging for rainwater harvesting three international perspectives. Chapter 8 IN: Memon, F. A. and Ward, S. Alternative Water Supply Systems. IWA Publishing, London. eISBN: 9781780405513.

Ward, S., Memon, F.A., Butler, D., 2010. Harvested rainwater quality: the importance of appropriate design. Water Science and Technology 61(7), 1707-1714.

Ward, S., Memon, F.A., Butler, D., 2012. Performance of a large building rainwater harvesting system. Water Research 46, 5127-5134.

White, I., 2011. Rainwater harvesting: theorising and modelling issues that influence household adoption. Water Science and Technology 62(2), 370-377.

Wirojanagud, P., Vanvarothorn, V., 1990. Jars and tanks for rainwater storage in rural Thailand, Waterlines 8(3), 29-32.

Zhang, Y., Chen, D., Chen, L., Ashbolt, S., 2009. Potential for rainwater use in high-rise buildings in Australian cities. J Environ Manage 91, 222-26.

Zhang, Y., Grant, A., Sharma, A., Chen, D., Chen, L., 2010. Alternative water resources for rural residential development in Western Australia. Water Resour Manage 24, 25-36.

Zhang, F., Polyakov, M., Fogarty, J., Pannell, D.J., 2015. The capitalized value of rainwater tanks in the property market of Perth, Australia. Journal of Hydrology 522, 317-325.

Zhu, K., Zhang, L., Hart, W., Liu, M., Chen, H., 2004. Quality issues in harvested rainwater in arid and semi-arid Loess Plateau of northern China. Journal of Arid Environments 57, 487-505.

Zobrist, J., Muller, S. R., Ammann, A., Bucheli, T. D., Mottier, V., Ochs, M., Schoenenberger, R., Eugster, J., Boller, M., 2000. Quality of roof runoff for groundwater infiltration. Water Research 34, 14551462. 


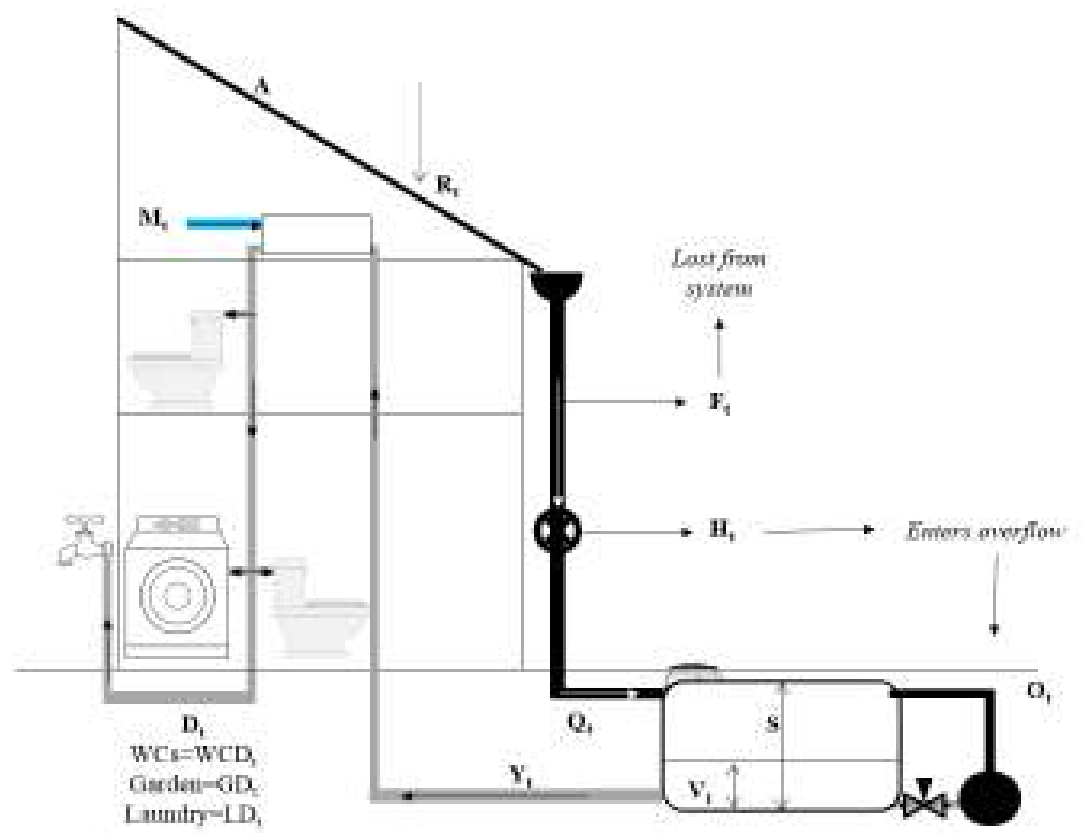

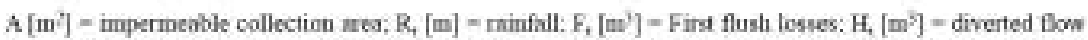

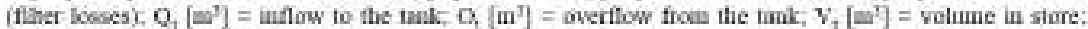

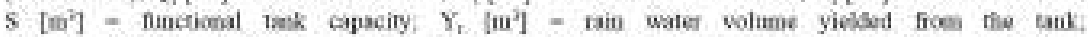
$\mathrm{M}_{1}\left[\mathrm{~m}^{\prime}\right]=$ wacer from mains $\mathrm{D}_{1}\left[\mathrm{~m}^{y}\right]=$ water demand, Subscript, relates to the time step of the sinmlation.

Fig. 1. Components of a typical RWH system. Arrows indicate water fluxes (adapted from Melville- 


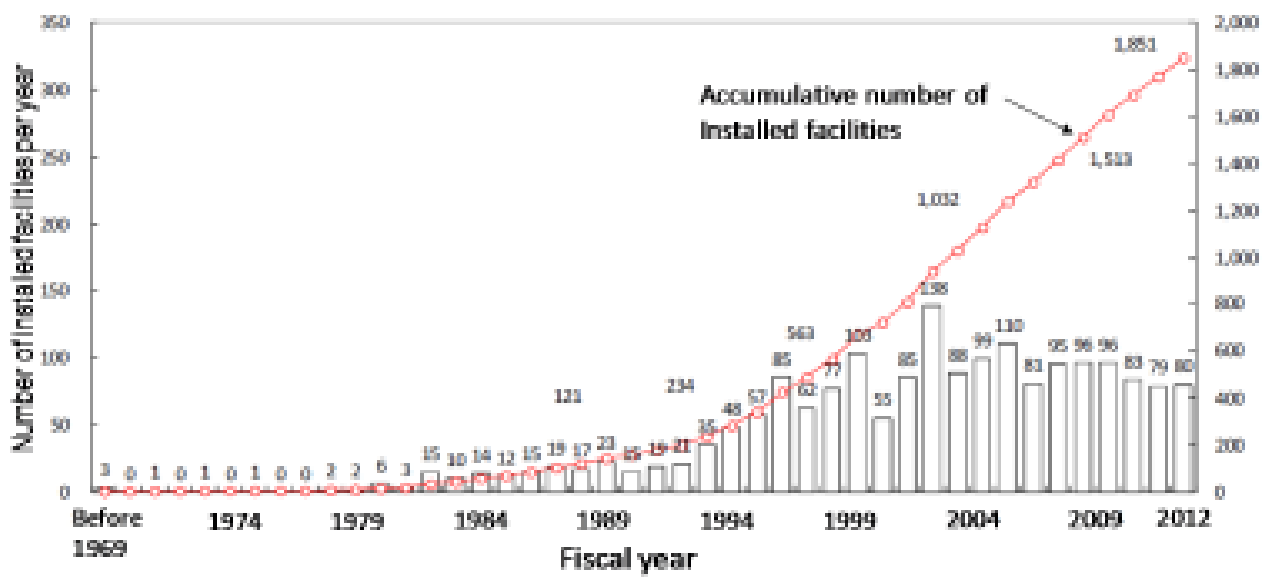

1283

1284 Fig. 2. Rainwater harvesting systems in public facilities and office buildings in Japan. An increasing 1285 trend is observed starting from early 1980s (adapted from MLIT, 2014)

1286

1287

1288

1289 